International Civic Engagement to Promote Peace

Presented at American Political Science Association Teaching and Learning Conference

February 2020

Patrick McNamara, Ph.D., University of Nebraska Omaha

\begin{abstract}
A troubled universe can no longer afford the luxury of pursuits confined to an ivory tower... Scholarship needs to prove its worth not on its own terms, but by service to the nation and the world.
\end{abstract}

-Oscar Handlin Quoted in Boyer (1996)

\begin{abstract}
This paper will share lessons learned from four years of teaching the Young Southeast Asian Leaders Initiative (YSEALI) program. YSEALI brings the best and brightest 18 to 25 years old leaders from Association of Southeast Asian Nations (ASEAN) to University of Nebraska Omaha (UNO) for training in civic engagement. The goals of this US Department of State-supported academic fellowship are to build trust between ASEAN countries and the US, peace within and between ASEAN countries, and active engagement in promoting democracy by ASEAN citizens. This paper explores lessons about comparative civic engagement, conflict resolution paradigms applicable in different contexts, and designing teaching materials that are flexible and appropriate in culturally, politically and religiously diverse settings.
\end{abstract}

\title{
Background on YSEALI
}

Launched in 2013, the Young Southeast Asian Leaders Initiative is the U.S. government's signature program to strengthen leadership development and networking in Southeast Asia. Through a variety of programs and engagements, including U.S. educational and cultural exchanges, regional exchanges, and seed funding, YSEALI seeks to build the leadership capabilities of youth in the region, strengthen ties between the United States and Southeast Asia, and nurture an ASEAN community. YSEALI focuses on critical topics identified by youth in the region: civic engagement, environment and natural resources management, and entrepreneurship and economic development. (U.S. Mission to ASEAN website) The YSEALI Institute at the University of Nebraska at Omaha (UNO) focuses on Civic Engagement.

The YSEALI Academic Fellows Program at UNO consists of 21 undergraduate and graduate students or recently graduated young professionals between the ages of 18 and 26 from Brunei, Cambodia, Indonesia, Malaysia, Myanmar, Philippines, Laos, Singapore, Thailand, Timor-Leste, and Vietnam who are making a difference in their communities, countries, and the region. The five-week institute at UNO includes an academic residency, leadership development track, an educational study tour to Boston, New York, and Washington, D.C., local community service activities, and opportunities to engage with American peers. (See YSEALI: Bringing the World to UNO video for more background on the YSEALI UNO Civic Engagement Institute)

We have designed courses in civic engagement, social entrepreneurship and conflict resolution for the YSEALI Fellows. These are supplemented with service learning activities that include the 
International Civic Engagement to Promote Peace

Presented at American Political Science Association Teaching and Learning Conference

February 2020

Patrick McNamara, Ph.D., University of Nebraska Omaha

Malcolm X Foundation, Intercultural Senior Center, Heartland Workers Center and Micah House for homeless families. YSEALI Fellows design Action Plans that they will present to State Department officials in Washington, DC, then implement when they are back in their home communities. We offer small seed grants for these Action Plans on a competitive basis each year. Many of these Action Plans focus on creating social justice for minorities and inclusion for youth.

\section{Lessons Learned}

The lessons we have learned are particular rich in comparative civic engagement. Not surprisingly, what works in Nebraska will not necessarily work in Phnom Penh. Adapting our teaching to be open to non-US models for civic engagement has been a welcomed challenge.

This section will explore three main ideas: comparative civic engagement; conflict resolution paradigms applicable in different contexts; and designing teaching materials that are flexible and appropriate in diverse settings.

Comparative Civic Engagement. The scholarship of engagement asks for academics to go beyond the noblesse oblige of service to community and actually collaborate with community to co-create knowledge. (O'Meara \& Rice, 2005) In many parts of the world, there is still the rigid hierarchy of experts over community people, lofty academics over mere citizens. Asia has that embedded hierarchical structure in its universities too. Where there is so-called service learning, it is often in the form of students volunteering in perceived needy communities.

The collaborative turn that is now happening in global civic engagement is challenging that traditional hierarchy. Saltmarsh (2017) writes that this collaborative turn "recognizes fundamentally that addressing complex social, political, environmental, health, and educational issues is more effective when solutions are not determined solely by specialized experts, thus opening up spheres of collaborative knowledge generation and problem solving in ways that redefine where knowledge comes from and who has expertise" (p. 3).

With YSEALI Fellows, we consciously tried to disrupt the hierarchy both in our UNO classrooms and their Southeast Asian environments. One simple way that we did this was by mixing teaching methods and reflective activities. For instance, each day was designed with some classroom learning and some community learning. 
International Civic Engagement to Promote Peace

Presented at American Political Science Association Teaching and Learning Conference

February 2020

Patrick McNamara, Ph.D., University of Nebraska Omaha

The classroom learning would sometimes take lecture form but usually involved dialogue, interactive exercises and simulations. We incorporated debrief and personal reflection time into these classroom activities. And each morning began with a personal and group reflection on the lessons from the day before. Often the YSEALI Fellows would question how what they were learning was relevant to their community back home. As teachers, we tried to listen and learn along with the Fellows.

The community learning in Omaha then on the study tour of Boston, New York and DC, was also rich with comparisons. Frankly, our UNO faculty along with faculty from UNO's sub-grantee partners on this YSEALI program - Arizona State University and Kennesaw State University learn as much from the program as the Fellows do. I am especially struck by the times when YSEALI Fellows challenge my assumptions about how government should be taking care of responsibilities that nonprofits do or philanthropy is really just a way for the rich to pay for exploiting their workers on their way to making more money.

The comparison of what is allowed in Myanmar, where civil society is still closely controlled by the military-backed government, to what is allowed in Brunei, in which journalists self-censor especially around issues involved the Sultan, can be great. Social media is leveling this playing field, but countries like the Philippines use trolls to shame those speaking out against President Duterte's government. We could go through each ASEAN country and compare and contrast them, but the point is that teaching these diverse YSEALI Fellows about the American model for civic engagement is not usually directly applicable to their country. So, deep listening and adjusting to what the Fellows tell us about their home situation is crucial to success.

Conflict Resolution Paradigms for Different Contexts. The conflict resolution paradigms work differently in ASEAN and the U.S. Building on the work of Fisher and Keashly (1991), the idea is that peacebuilding methods must be contingent on the particular circumstances of the conflict. So, the political, cultural, religious, economic and other circumstances must all be part of the analysis and then resolution. A few reflections from our YSEALI program follow.

The differences between how government, philanthropy and civil society co-exist in the U.S. and in Southeast Asia are stark. And so too, the comparison between different ASEAN countries can also be great. For instance, Singapore is a small city-state that has long been dominated by a single political party, the People's Action Party, while Indonesia is a multi-party democracy. Vietnam is a communist party system, but also displays many elements of dynamic entrepreneurship that would be more familiar to capitalist countries. 
International Civic Engagement to Promote Peace

Presented at American Political Science Association Teaching and Learning Conference February 2020

Patrick McNamara, Ph.D., University of Nebraska Omaha

Even within countries, there are vast differences. An example is in the southern Thailand where minority Muslim communities in the Pattani and Yala regions have been fighting the majority Buddhist regime of the north for decades (Beech \& Jirenuwat, 2019). One of our YSEALI Fellows is head-of-school an Islamic elementary school in southern Thailand. She learned a lot from our visits to public schools in Omaha, but kept saying how the context in which she worked - where unemployment drove many young people to extremist organizations - was not so comparable to the U.S. She had to skillfully blend Sharia Law, so that the local community would accept her school, with patriotic curriculum, so the Thai government would allow her school to operate, which is something a U.S. school principal does not deal with in our strict church-state divide.

Rothman (2014) writes of various methods of intervention such as consultation, arbitration, mediation, peacekeeping, etc. that need to be matched with both the stages of the conflict and whether resource, identity or objectives are at its heart. The relevance to our YSEALI program is that we ask the Fellows to analyze their own community conflicts then come up with resolution possibilities often then implemented through their Action Plans. We suggest that, "If you've seen one conflict, you've seen one conflict" which challenges the universalization of interventions and solutions. So, each conflict and therefore each resolution is unique. This exercise forces Fellows to try to imagine removing themselves as a party to and be a neutral analyst of the conflict (a hard task for most).

Flexible and Appropriate Teaching Materials. The curriculum has evolved over the four-and-ahalf years we have administered this YSEALI grant from the U.S. Department of State. In the first year, the courses were more American-centric with our unexamined assumptions built in. Recognizing that these biases were not necessarily serving the YSEALI Fellows, we incorporated more dialogue and elicitive learning (Lederach, 1995) in years two and three. By the fourth year, we saw the need to integrate even more community collaboration, so we designed more ways of learning with and from those community members who have been in the trenches for decades.

The readings and other assigned materials have also evolved. While there is still a grounding in the revolutionary and especially the civil rights history of the U.S., we are focused more on general civic education that would be applicable to whatever context. We have received positive feedback from our YSEALI Fellows on this. One wrote, "Overall this is an amazing program... It give me a chance to learn and experience a lot of things thus I can implement, learn and share back to my country." And another Fellow wrote, "My favourite part was the discussions on civic engagement components. This provided me an overview of the things I can do or improve on my organization to deliver our goals to my community" (Lubischer, Treacy \& Harder, 2019). 


\author{
International Civic Engagement to Promote Peace \\ Presented at American Political Science Association Teaching and Learning Conference \\ February 2020 \\ Patrick McNamara, Ph.D., University of Nebraska Omaha
}

\title{
Conclusions
}

We have a number of conclusions to draw from this study. First, we need to continue our humble approach when teaching, especially in cross-cultural settings. It is almost always detrimental to the inquisitive classroom to have a professor with that sage-on-the-stage attitude. When the teacher is intentionally vulnerable, mutual learning happens (Palmer, 1998). To approach each classroom moment as an opportunity to learn from each other is key and this YSEALI program has borne that out.

Second, we are constantly trying to get out of the classroom into the community, not as volunteers assisting the needy but as co-creators of knowledge. For our international students to see this has inspired them to return to their home communities with a different attitude. As one YSEALI Fellow put it in a video about the program, "YSEALI expanded my horizon to see beyond what I've been doing the past few years... and knowing that there are others around the world that are also wanting to make an impact on our world" (YSEALI: Bringing the World to UNO).

Third, we realize that what works in one place will not necessarily work in another. You must understand the community culture of a place then design programs appropriate for that community culture (McNamara, 2007). Our YSEALI program has tried to incorporate this into the curriculum and teaching methods with deep analysis of each Fellow's own community before suggesting any interventions. This evolved over the course of our program and will, no doubt, evolve further as we reflect and continue to grow.

Some ongoing questions for further reflection include:

- How do others adapt teaching civic engagement for different contexts?

- What lessons about community engagement have others learned from teaching international students?

- How can service learning activities help in teaching civic engagement? 
International Civic Engagement to Promote Peace

Presented at American Political Science Association Teaching and Learning Conference

February 2020

Patrick McNamara, Ph.D., University of Nebraska Omaha

\section{Sources}

Beech, H. and Jirenuwat, R. (2019, November 6). 15 Killed in Southern Thailand in the Worst Violence in Years. New York Times.

https://www.nytimes.com/2019/11/06/world/asia/thailand-violence-insurgency.html

Boyer, E. L. (1996). The Scholarship of Engagement (pp. 11-21). Journal of Public Service and Outreach, Vol. 1, No. 1.

Fisher, R. J. and Keashly, L. (1991). The Potential Complementarity of Mediation and Consultation within a Contingency Model of Third Party Intervention (pp. 29-42). Journal of Peace Research, Vol. 28, Issue 1.

Lederach, J. P. (1995). Preparing For Peace: Conflict Transformation Across Cultures. Syracuse, New York: Syracuse University Press.

Lubischer, R., Treacy, D. L. and Harder, J. (2019). YSEALI Institute on Civic Engagement at University of Nebraska at Omaha (UNO): Fall 2019 Evaluation Report.

O'Meara, K. and Rice, R. E. (Eds.) (2005). Faculty Priorities Reconsidered: Encouraging Multiple Forms of Scholarship. San Francisco: Jossey-Bass.

McNamara, P. (2007). Collaborative Success and Community Culture: Cross-sectoral Partnerships addressing Homelessness in Omaha and Portland.

https://digitalcommons.unomaha.edu/studentwork/5

Palmer, P. (1998). The Courage to Teach: Exploring the Inner Landscape of a Teacher's Life. San Francisco: Jossey-Bass.

Rothman, J. (2014) Conflict Engagement: A Contingency Model in Theory and Practice (pp. 104116). Peace and Conflict Studies: Vol. 21, No. 2.

Saltmarsh, J. (2017). The Collaborative Turn: Trends and Directions in Community Engagement (pp. 3-15). In Sachs, J. and Clark, L. (Eds.), Learning Through Community Engagement. Singapore: Springer.

U.S. Mission to ASEAN website. https://asean.usmission.gov/yseali/yseali-about/

YSEALI: Bringing the World to UNO. Video at https://www.youtube.com/watch?v=mocNbRII8PY 